\title{
HIGH TECHNOLOGY CITY OF BANGLORE,
}

KARNATAKA, INDIA

\author{
Alfiana Yuli Efiyanti \\ Program Pendidikan IPS, Fakultas Tarbiyah \\ Universitas Islam Negeri Maulana Malik Ibrahim Malang \\ Jl. Gajayana No. 50 Malang
}

\begin{abstract}
Abstraksi
Bangalore, sebuah kota yang merupakan ibu kota propinsi Karnataka, salah satu Negara bagian India, telah membuktikan diri mampu mengembangkan diri menjadi kota industri yang yang berteknologi tinggi. Kota ini dikenal sebagai pusat kota yang produktifitasnya sangat tinggi. Industri sotware berkembang pesat sehingga mengundang banyak investor asing, yang pada akhirnya mampu meningkatkan kesejahteraan Negara bagian tersebut. Keberhasilan ini diawali dengan didirikannya sebuah Universitas Teknologi unggulan di Bangalore, pada tahun 1909. Dibarengi dengan kondisi alam yang cukup ideal dan beberapa kebijakan pemerintah termasuk revolusi teknologi, perkembangan Bangalore dapat direkomendasikan sebagai bahan rujukan bagi pembuat kebijakan, terutama bagi pemekaran suatu daerah menjadi sebuah kota berteknologi tinggi.
\end{abstract}

Kata Kunci: kota industri berteknologi tinggi, Bangalore, politik regional

Bangalore, the capital of Karnataka, India, has been famous as a high technology city. Software industry is the leading company that are operated in that city. Until 2002, the total number of software professionals is over 80,000 , and about 116 new Software Technology Park units were established.

It should be recognised that the development of Bangalore as a high technology city has a long story. Beside some factors endowment such as a beautiful climate, the most important started point of the development was the existed of the university in Bangalore, combined with the government policies. In 1909, attracted by the comfortable climate, an Indian industrialist, Jamsetji Nasarwanji Tata, established an 'India's Premier Science and Technology University' in Bangalore. At that time, Jamsetji Nasarwanji Tata did not anticipate that his technical school would lead to a computer industry concentration in Bangalore. (Easterly, 2001:187). But it proved that the existence of that university have provided many skilled labor force. 
In general, the Indian government has implemented a policy concerning technology development called 'Technology Resolution' since 1948. The strategy of development had begun by import substitutions policies, including restrictions and high tariffs on imports, elaborate import licensing procedures, export subsidies, control on foreign direct investment and an overvalued exchange rate.

The Indian innovation system is under the responsibility of the government. It is understood that the Research and Development is also dominated by the central state, about three fourth of the entire Research and Development expenditure.

The Research and Development have been emphasised to:

1. Defense sector - electronic, aviation and space, missiles

2. General infrastructure support - atomic energy, electrical power, communication

3. Basic science - astrophysics

In 1971, the Government implemented the other policies specialize in the computer area by establishing the Department of Electronics (DOE). This department required high skill labour and high technology. One of the DOE programs promoting the generation of computer software, particularly for export oriented. Therefore, it was protected from foreign competition. Until mid 1980, foreign investment was not permitted, except foreign investment that could lead some technology transfer, such as ICL and IBM that are the largest providers of hardware in India.

DOE encouraged the participation of public sector projects which dealt with software development. A state computer service and maintenance was established in 1976 and monopolised the most of public sectors software development and maintenance. The company was CMC (Computer Maintenance Corporation). It also provided all foreign systems installed in the country including IBM.

The local software industries development quite fast. It was mostly caused by the more complicated needs of the software, when in the mid-1970 software that provided by IBM and ICL that included in their hardware were not sufficient anymore for fulfil the needs. Since that, the market for commercial 
software were more developed. The new local software industries established were Tata Consultancy Services (TCS), Tata Burroughs (TBL) was formed in 1978 as a joint venture between Tatas and Burroughs, an American company. Both companies, TCS and TBL, now became a largest software exporters.

The high technology development of in Bangalore become fast when a new liberalisation Computer Policy was introduced in November 1984. The policy reduced many constraints on the industry and open a wide opportunities to foreign companies to establish or invest their equity in India. The other policy concerning software policy that was called a 'flood in - flood-out' was introduced in 1986. Under the policy, allowing imports to 'flood in' in the hopes that eventually exports would 'flood out'.

The results of those policies appeared before long. The Texas Instrument (TI) proposed to established a 100\% export-oriented, foreign owned and operated subsidiary in Bangalore in 1984. The enter of TI on to Bangalore has become the most important starting point of the development of IT companies until today.

The Software Technology Parks of India (STPI) also plays an important role in the case of technology development. It began its operational in 1988. Although it was under the Indian Government of Electronics, the functions is independently. The purpose of that institution are Encourage and supports software exporters by:

1. giving $100 \%$ export-oriented firms a tax-free status for 5 years within the first eight years of operation.

2. Providing those firms with office space and computer equipment, access to high-speed satellite links and an uninterrupted supply of electricity.

3. Providing other services such as import certification, software valuation, project approvals, market analysis, marketing support and training.

4. 'Single window clearance' for projects. For the smaller projects, i.e. less than Rs. 30 million, only STPI clearance is required, $100 \%$ foreign equity is permitted and there are no restrictions on location.

5. Providing connection and integrated network, whereby subscribers can posses an acccess to the internet, and would give them e-mail, remote log in and file-transfer services and also access to the WWW. 
6. Providing video-conferencing services between Bangalore and the rest of the world.

Beside in Bangalore, STPIs are currently also located in Bhubaneswarm Delhi/Noida, Gandhinagar, Hyderabad, Pune and Thiruvanathapuram.

\section{DEVELOPMENT INDICATOR OF HIGH TECHNOLOGY REGION OF KARNATAKA/BANGALORE}

\section{GDP and GDP per capita}

Karnataka has become one of the richest states of India. In the year 20002001, the Gross State Domestic Product (GDSP/GDP) of Karnataka was 104,818 Crore Rupees (Crore refers to ten million, so it is 1048,14 billion Rupees) that increased 17,0008 Crore Rupees from the year 1998 - 1999 (see table 1.). It was 5.5 percent of Indian total GDP in the year 2000 - 2001. From table 1, we can also see that Karnataka seventh richest sate according to the GDP rank among 32 states of India.

According to GDP per capita, Karnataka was thirteen richest state with the 15,390 Rupees in the year of 1998 - 1999. But in the year of 2000 - 2001, Karnataka jumped to eleventh richest sate with the 18,324 Rupees per capita. Figure 3 provides general overview of the level of Indian per capita income amongst the states of India. The average per capita income of India was 11,424 Rupees between 1998/1999 - 2000/2001. Karnataka's per capita income was higher that the average line. The poorest states such as Bihar and Uttar Pradesh have less than 5,000 Rupees per capita income.

The regional disparities amongst Indian sates in some extent can be explained with their industrialization level. According to the structure of economy of Bihar (the poorest one), agriculture is still the dominant sector of the economy. On the other hand industry and service sector are dominant the richest states.

\section{Software export}


The rapid development of IT industrial in Bangalore has taken Bangalore in the first place of the growth software exports comparing to the other export cities in India. Please examine the graph below.

Graph 1. Software Export Cities in India, 2000/2001

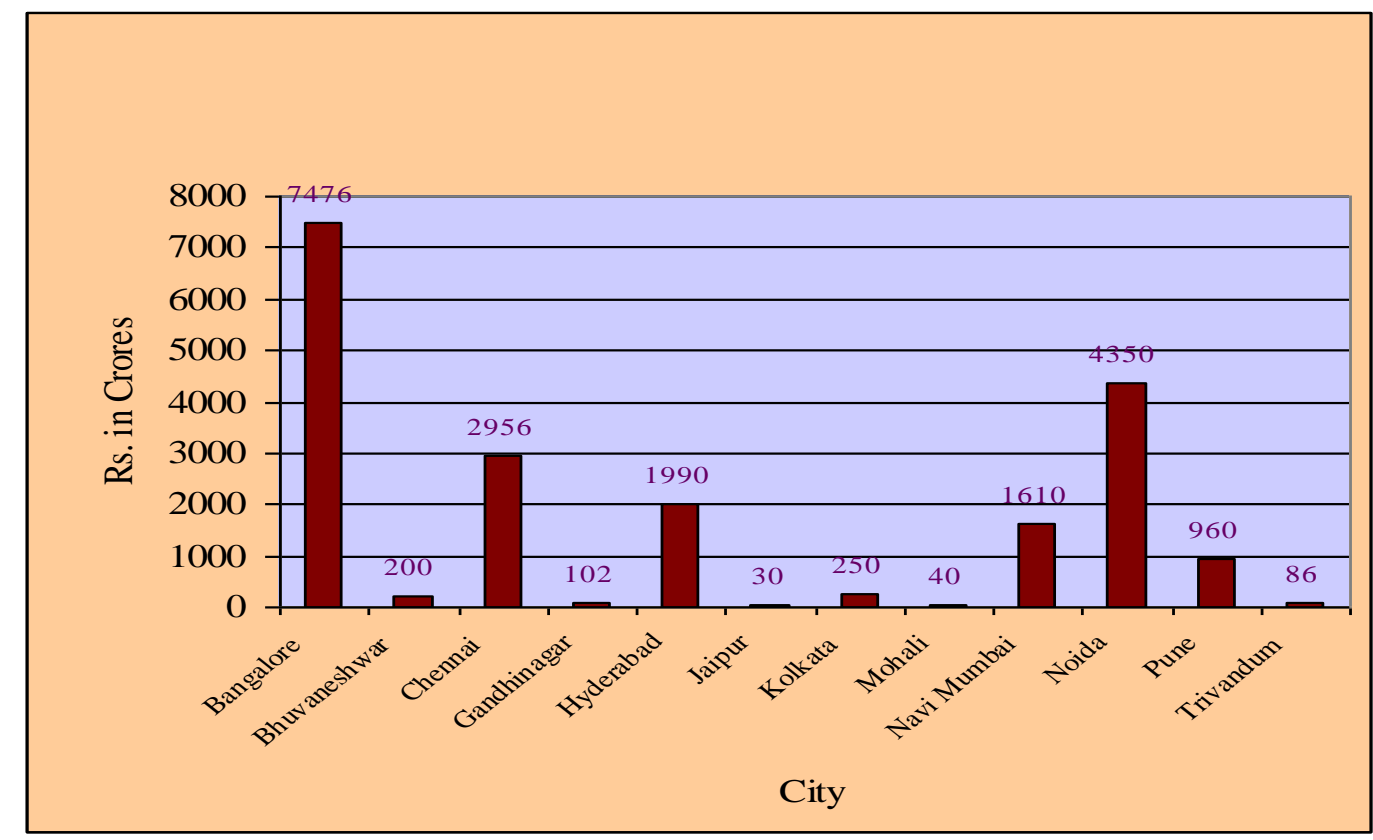

Source: Department of IT and Biotechnology, Govt. of Karnataka

The graph shows the amount of export of software in each software export cities in India, in the year of 2000/2001. With the amount of 7475 Rs. Crores, Bangalore was in the first place among the other cities. Noida and Chennai were in the following second and third place.

Meanwhile, the growth rate of the software export during $1999-2003$ is showed in the following graph. 
Graph 2. Growth rate of the software exports from Bangalore, 1999 - 2003

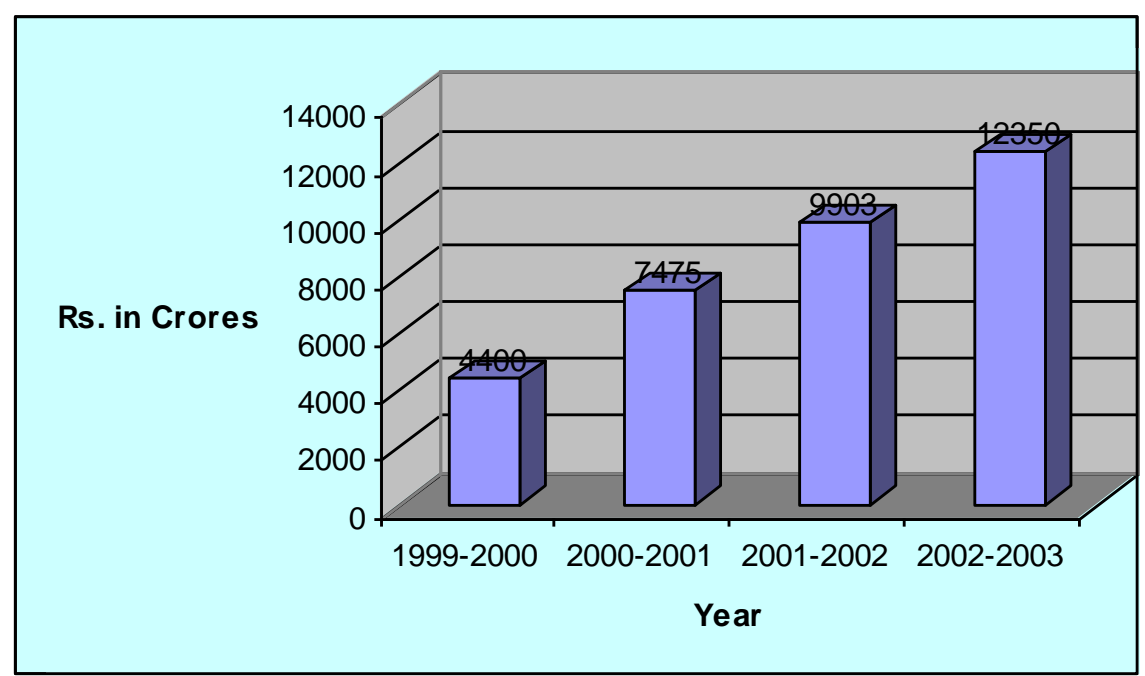

Source: Department of IT and Biotechnology, Govt. of Karnataka

In the year 1990/2000 to $2000 / 2001$, growth rate of the software exports was $69.99 \%$. And in the year 2000/2001 to the year 2001/2002 it was 33\% following by $25 \%$ from the recent year,, 2001/2002 to the year 2002/2003.

\section{REASONS OF THE SUCCESS OF BANGALORE}

\section{Internal Potential}

The development of Bangalore become a high technology city has been influenced by the characteristics of that region. Geographically, the region of Karnataka is located in the south, connecting directly to the Arabian Sea. Bangalore itself, located on the Deccan Plateu, in the center of the Indian peninsula, which is $1000 \mathrm{~m}$ above the sea level. Besides, other specific condition of Karnataka also could be considered as the successful of the development of innovative such as the Huge parks of British origin, which is usually called 'Garden City'.

The important elements of the technological infrastructure were already established in the colonial era. For example institution of Research and Development, Aircraft Maintenance, etc. And after the independence, the first Prime Minister of India, Jawaharlal Nehru, had vision for Bangalore 'City of the Future', he sought to turn it into India's intellectual capital. As a results, since 
1950s, many Indian's public sector high-tech industries have been located in Bangalore.

Some sensitive industrial strategies also had been located in Bangalore because of the safety reason, that is in fact, Bangalore is distance from India's border. In this case, In 1956 and 1960, large public sector undertaking like Bharat Electronics Limited (BEL) and Hindustan Aeronautics Limited (HAL) were established in Bangalore. The other strategically industries was the Indian Space Research Organisation and Bharat Heavy Electronics Limited (BHEL) that was established in 1970s.

One of the reason that the Texas Instrument - which was led the boom of software exports from Bangalore - attracted to invest in Bangalore was because of its strong educational system in theoretical sciences and engineering, very large English-speaking, and highly-skilled labour forced, but low cost. The establishment of the India's premier Science and Technology University by Jamsetji Nasarwanji Tata that was mention in the section 3.1 had been the most important starting point in the education system in Bangalore.

\section{External Contributors}

\section{Foreign Direct Investment}

The internal potential of Karnataka/Bangalore have attracted the foreign companies to invest, open subsidiaries or located their branches in that region. This situation like the complementary situation that have supported the success of Bangalore. The arrival of Texas Instruments (TI) had led other companies decided to open or located subsidiaries in Bangalore. In 1989, Hewlett Packard set up a $100 \%$ owned subsidiary and $100 \%$ export-oriented. It was following by other companies such as VeriFone and Motorola.

Other type of FDI in Bangalore has been 100\% export oriented, but they are developing software for the internal use, providing support and maintenance for the software systems in their world wide operations. They have no ambitions in developing and marketing their software packages.mThey selected Bangalore because of the positive condition of Bangalore. Companies that set up their business with those reasons were Siemens and Deutsche Bank. 
The term of partially owned subsidiaries of foreign multinational companies also exsisted in Bangalore. Digital Equipment India Limited (DEIL) is a 51\% subsidiary of Digital Equipment Corporation (DEC) in the United States. The focus of DEIL's operational was on providing software for Digital hardware in India. A number of highly skilled senior consultants were employed as advisors who should be travel to other DEC subsidiaries.

PSI Data Systems Ltd. is also the partially model. It is the subsidiary of Groupe Bull in France. The groupe bull acquired 51\% of the shares. PSI's core projects were competency in the area of software and services. Currently, the United States and Europe are the largest portion of it's revenues.

The third characteristic of FDI in Bangalore was Joint ventures between multinational companies and Indian companies. There are some advantages could be gained in the form of joint ventures. From the Indian side, they have opportunities to establish a reputation and a client base in foreign market. For the foreign companies, Indian partners would help them to have easier access to enter Indian markets, as they may already have and established reputation. Moreover, Indian companies have been familiar with bureaucratic procedures of their own countries.

The largest joint venture is Tata Information Systems Limited (TISL), which is a joint ventures between IBM and Tata Group. TISL undertakes software development for IBM, but IBM is not its only customers. It would focus to expand the customer base in the US, Europe and East Asia.

One other example of joint venture is TCS that is joint between Microsoft Corporation and Tata Consultancy Services. TCS provides software development, consultancy and value-added services for Microsoft's Windows NT operating system.

\section{Network Support System}

A network system that are played by some actors seems working well in the case of development of high-tech district of Karnataka/Bangalore. Each actors are supported by some elements and they have connection and related to each others. The main actors could be categories to three groups. (FromholdEisebith, 1999:254) 
1. The Indian industrial community, consisting of private firms, joint ventures of Indian with foreign firms, and Public Sector Enterprises (PSE).

2. The Indian scientific and educational community, comprising the locall institutions of Research and Development and higher education

3. The foreign industrial community, formed by the branches of MNCs

Figure 3. Support systems in the technology region of Bangalore

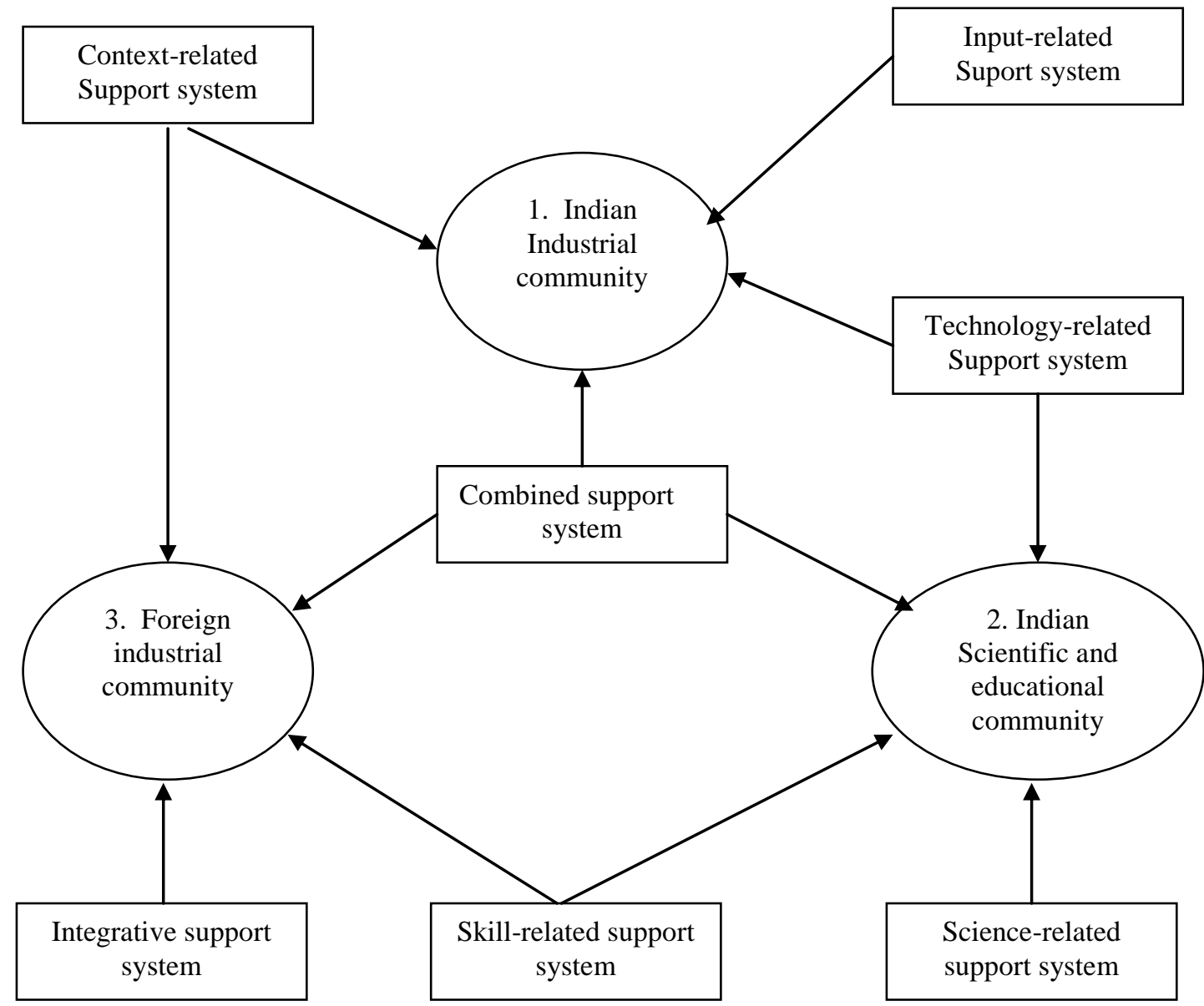

Source: Malecki, E.J, “Making Connections”, 1999.

The figure above describe how the actors and supports components which was mentioned in the table 1 work. There are 3 main actors, no. 1, 2, and 3.

The Indian industrial community (1) linkage is characterised as an 'inputrelated support system'. The Indian scientific and educational community (2) support system could be defined as the 'Science-related Support System'. It means that there are many collaborations among the group that are related to the 
science, such as the exchange of scientific staff, personal relationships between Research and Development laboratories and the universities. Those relationship have created an intense informal information exchange.

Meanwhile, in the Foreign industrial community and the foreign company branches (3), there is a linkage that is called an 'integrative support system'. The system integrates the foreign community to the local environment.

The role of the technology-related support system has helped to develop both the Indian industrial community (1) and Indian scientific and educational community (2). However, in the Indian industrial community, the integration is usually limited to PSEs and to companies that have spun off from local laboratories.

The major efforts of the IT companies is to improve the local companies. In this connection, there is a 'Context-related Support System'. To do so, some associations were formed in order to solve any problems. For instance, Bangalore Forum of IT which is organised by sector, and Electronics City and Peenya Industrial Area Associations which is organised by locations. The meeting among the top executive of the foreign industrial companies and the Indian industrial companies are conducted in the regularly time. In this forum, a lot of problems and issues concerning the development of the industries and related matters are discussed, such as infrastructure constraints, bureaucratic impediments, the enermous brain drain, and also joint initiatives for social work. The most important thing in this context is the possibility of the local companies to make a deep relationship with the big MNCs. The small local companies could act as the suppliers or sub contracting relationships.

The Indian scientific and education community (2) and the foreign industrial community (3) development are depended on the availability of the skill manpower. The system of 'Skill-Related Support System' plays the important role in this case.

In the whole activities, the three of the main actors have strong linkages with the joint venture companies which was established by high technology oriented PSEs with foreign partners. 


\section{SOURCES}

Frommhold-Eisebith, M., "Bangalore: A Network Model for Innovation oriented Regional Development in NICs?" in Malecki, E.J.: "Making Connections", Aldesha, 1999.

Skeldon, R., "Population Mobility in Developing Countries", chapter 8, London, 1990.

Department of IT and Biotechnology, Govt. of Karnataka

Worldbank Online Report, "Assessing Development Outcomes", Chapter 1, at http:/ / Inweb18.worldbank.org.

Ministry of Statistics and Programme Implementation, Indian website at http://mospi/nic.in. 